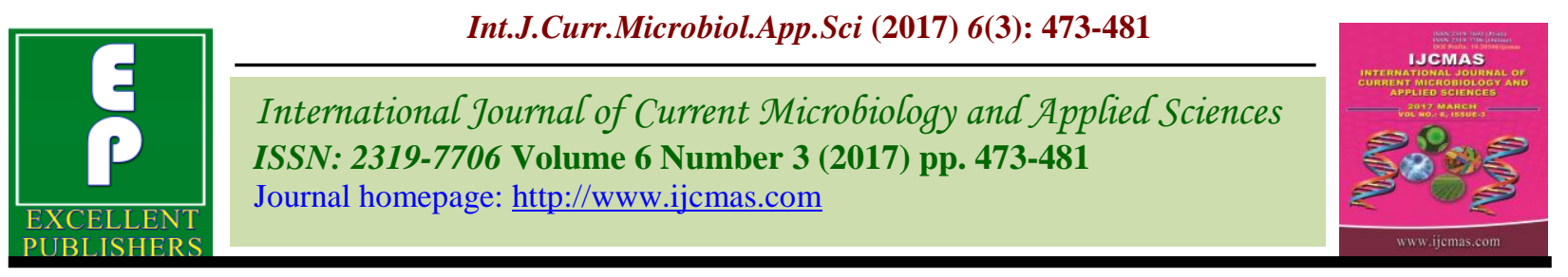

Original Research Article

https://doi.org/10.20546/ijcmas.2017.603.055

\title{
Molecular Characterization of Tomato Leaf Curl Virus (ToLCV) in South Gujarat, India
}

\author{
M. Vanthana ${ }^{1}$, L. Mahatma ${ }^{1}$, T.V. Ghevariya ${ }^{1}$ and R. Saranya ${ }^{2}$ \\ ${ }^{1}$ Department of Plant Pathology, NMCA, NAU, Navsari, Gujarat 396 450, India \\ ${ }^{2}$ Department of Plant Pathology, JAU, Junagadh, Gujarat 362 001, India \\ *Corresponding author
}

\begin{abstract}
A B S T R A C T

\begin{tabular}{|l|}
\hline Ke y w or d s \\
Begomovirus, \\
$\begin{array}{l}\text { DNA-A, ToLCV, } \\
\text { PCR, Phylogeny }\end{array}$ \\
\hline Article Info \\
\hline $\begin{array}{l}\text { Accepted: } \\
\text { 10 February } 2017 \\
\text { Available Online: } \\
\text { 10 March } 2017\end{array}$ \\
\hline
\end{tabular}

The present study was conducted to characterize Leaf Curl Virus infecting tomato in south Gujarat region showing typical leaf curl symptom with upward/downward curling along with vein clearing of the leaves. A part of DNA-A molecule of $~ 1200$ bp was amplified with a Begomovirus specific primers confirming it to be Begomovirus. On sequencing, a 1125 bp nucleotide sequence (Accession no- KU921251) was obtained. Amplified fragment had two genes viz., virus coat protein $(V I)$ gene and pre coat protein $(V 2)$ gene. The sequenced virus showed highest identity (94\%) with Tomato leaf curl Gujarat virus [Nepal] segment DNA A, [AY234383.1] followed by $93 \%$ sequence identity with thirteen different tomato Begomoviruses which were the strains/isolates of Tomato leaf curl Gujarat virus or Tomato leaf curl New Delhi virus [DQ629101.2]. The virus was named as Tomato leaf curl Gujarat virus [Nepal] [India:Nvs: LC:Tom:2016] and was abbreviated as ToLCGV [Nepal] [India:Nvs: LC:Tom:2016]. Phylogenetic analysis of the sequenced virus with the other Begomoviruses of the different crops from the different location indicated that the virus was typically a leaf curl virus.
\end{abstract}

\section{Introduction}

Tomato is one of the most important vegetable crops grown throughout the world. It helps in reducing cancer, cardiovascular diseases and cholesterol (Sachan, 2004) and hence known as protective food. The major constraint for tomato growers is the occurrence of Tomato leaf curl disease. Among the different viruses, Tomato leaf curl virus (ToLCV) is the most serious constraints for the production of tomato in India (Srivastava et al., 1995). ToLCV belongs to genus Begomovirus, family Geminiviridae characteristically have circular single- stranded DNA genomes packaged within twinned (so-called geminate) particles. The bipartite genome comprises two singlestranded DNA (DNA-A and DNA-B) components of similar size $(2.5-2.8 \mathrm{~kb})$. The nucleotide sequences of DNA-A and DNA-B are quite different, except for a short common region of $\sim 200$ nucleotides found to be very similar in the two DNAs. Incidence of tomato leaf curl disease in India was first reported from northern region (Pruthi and Samuel, 1939) and subsequently from various parts of the country. The first conclusive etiology of ToLCD in India as a Geminivirus was reported by Muniyappa et 
al., (1991) and full length sequencing of ToLCV by Srivastava et al., (1995). In Gujarat ToLCV was first reported by Chakraborty et al., (2003). Recently, ToLCD has become the prime limiting factor for tomato production in Gujarat. It is persistently transmitted by whitefly Bemisia tabaci (Gennadius) (Hemiptera: Aleyrodidae). The disease causes nearly 40100 per cent yield loss depending upon the stage of infection and severity (Chakraborty et al., 2003). A sharp increase in the incidence of ToLCD (up to 100\%) is being noticed since 1960s after introduction of high yielding tomato varieties. Severe incidences of the ToLCD have been observed in all the tomato growing areas of the south Gujarat, however it was difficult to acertain the virus on the basis of symptoms produced. Therefore, attempts were made to characterize the virus.

\section{Materials and Methods}

\section{Source of viral sample}

Samples from the tomato crop sown in the field of Navsari Agricultural University were collected showing typical leaf curl symptom with upward/downward curling along with vein clearing of the leaves.

\section{Molecular characterization}

\section{Isolation of viral DNA}

For DNA extraction, fresh leaf (500mg tissue) from the infected plant were taken and homogenized in Eppendorf tube using liquid nitrogen. After complete homogenization, $700 \mu l$ of CTAB extraction buffer was added and incubated the Eppendorf tube at $60-65^{\circ} \mathrm{C}$ for one hour in water bath. Isolation of DNA was done by the CTAB method given by Doyle and Doyle, 1987 with slight modification. The quantity of the isolated DNA was measured using spectrophotometer (Nanodrop). DNA quality was tested by running on 0.8 per cent agarose gel and documented the gel by GelDoc (SYNGENE, UK).

\section{PCR analysis}

The virus isolated by Doyle and Doyle (1987) method was amplified using PCR. A primer pair LVF+LVR (LVF=TCTCAACTTCGA CAGCCCATC + LVR=ATAGGTCCAGTG GCGTTTGA) for the amplification of the DNA-A molecule of Begomovirus was used for the amplification of the DNA-A molecule of the virus isolated. PCR amplification was carried out in $25 \mu \mathrm{l}$ reaction volume containing $50 \mathrm{ng}$ genomic DNA, $2.5 \mu \mathrm{l} \mathrm{PCR}$ buffer (MBI Fermentas, Hanover, USA), 200 $\mu \mathrm{M}$ dNTPs (Merk, Bangaluru, India), 1.5 U Taq DNA polymerase (MBI Fermentas) and $0.4 \mu \mathrm{M}$ primer using a thermal cycler (Eppendorf, Germany).

The programme was performed as 1 cycle of $94^{\circ} \mathrm{C}$ for $2 \mathrm{~min}$ and 35 cycles of $94^{0} \mathrm{C}$ for 45 sec, $52^{0} \mathrm{C}$ for $1 \mathrm{~min}, 72^{0} \mathrm{C}$ for $1 \mathrm{~min}$ then a final extension step at $720 \mathrm{C}$ for $5 \mathrm{~min}$. The PCR products were run on 2.0 per cent $(\mathrm{w} / \mathrm{v})$ agarose gel in $0.5 \mathrm{X}$ TBE buffer at $100 \mathrm{mV}$ for $1 \mathrm{hr}$. Gels with amplified fragments were visualized and photographed under UV light using SYNGENE Bio imaging system.

\section{Purification and sequencing}

The amplified product of PCR was purified and used for sequencing. Sequencing was done by adding Terminator Ready Reaction Mix (Big Dye sequencing kit 3.1v provided by Applied Bio systems).

Data were retrieved from the sequencer and further analysed for similarity index using NCBI-BLASTN and multiple nucleotide (nt) sequence alignments using CLUSTALW (2.1). ORFs of the sequence was also obtained using Open Reading Frame finder of the NCBI software. 


\section{Phylogenetic tree analysis}

Phylogenetic tree was constructed by using online software Neighbor-joining method with 1000 bootstrap replication in the MEGA version 4.0 (Tamura et al., 2007). The representative species, strains and variants of different Begomovirus species from the different crops and geographical location were selected for the phylogenetic analysis.

\section{Results and Discussion}

Symptoms of the disease observed during the investigation were typical leaf curl symptoms with the upward/downward curling along with the vein clearing of leaves. Fruit, if produced at all, were small, dry and unmarketable. Leaves were often stiff, thicker and of leathery texture rather than flaccid. Affected plants grew slowly and became stunted or dwarfed. The flowers appear normal. No chlorotic or yellowing of the leaf lamina could be seen. Viral DNA was successfully isolated from symptomatic younger leaves of Tomato plants by CTAB method. PCR amplification to amplify a part DNA-A molecule showed $\sim 1200 \mathrm{bp}$ band of DNA-A molecule. Amplified fragment was purified and sequenced in an automated DNA sequencer by the Cycle sequencing method and a 1125 bp nucleotide sequence was obtained. This was deposited to the Genebank, NCBI and Accession no. KU921251 was obtained. ORF obtained by the ORF finder of the NCBI software indicated that the sequence is having two ORF. Comparison of the sequence with the other standard universal ORF of the DNA-A molecule indicated that the amplified fragment have two genes viz., virus coat protein $(V 1)$ gene and pre coat protein $(V 2)$ gene. On blasting the sequence using BLASTN program the virus showed highest identity (94\%) with Tomato leaf curl
Gujarat virus [Nepal] segment DNA A, [AY234383.1] followed by 93\% sequence identity with thirteen different Begomoviruses of tomato which were strains/isolates of Tomato leaf curl Gujarat virus or Tomato leaf curl New Delhi virus (Table 1). For the nomenclature and demarcation of species, strains and variants of the species of the virus the recent criteria proposed by Fauquet et al., (2008) and subsequent guidelines given by ICTV (Anon 2015) were used. Accordingly the sequenced isolate has been considered as tentative strain of Tomato leaf curl Gujarat virus [Nepal] and named as Tomato leaf curl Gujarat virus [Nepal] [India: Nvs:LC:Tom: 2016] and is abbreviated as ToLCGV [Nepal] [India: Nvs:LC:Tom: 2016]. Representative species, strains and variants of different Begomovirus species from the different crops and geographical location were selected for the phylogenetic analysis (Table 2). The Dendrogram was constructed from the aligned sequences using the neighborjoining method and bootstrap option of Tree conversion (1000 bootstrap replicates). A total of 56 different viruses including recently sequenced virus during present investigation [Accession no. KU921251] were aligned together in a phylogenetic tree (Fig. 1). The virus under investigation was found aligned closely with different strains of Tomato Leaf Curl Gujarat virus. All the Begomovirus claded in two distinct clads.

One clad comprised of all the Begomoviruses infecting different crops viz., cotton, cassava, okra, gourds, tomato, papaya and chilli. Another clad consisted of species, strains and variants of different Begomovirus infecting legumes were obtained. This indicated that the Begomovirus infecting legumes are entirely distinct from the Begomoviruses infecting other crops. 
Table.1 Percent identities (nucleotide) between part of DNA-A of [ToLCGV[Nepal][India: Nvs: LC:Tom:2016]] with the selected Begomoviruses reported worldwide

\begin{tabular}{|c|c|c|c|}
\hline Description & Acronym & $\begin{array}{c}\text { Accession } \\
\text { number }\end{array}$ & $\begin{array}{c}\% \\
\begin{array}{c}\% \\
\text { Nucleotide } \\
\text { sequence }\end{array}\end{array}$ \\
\hline $\begin{array}{l}\text { Tomato leaf curl Gujarat virus - [Nepal] } \\
\text { segment DNA-A, complete sequence }\end{array}$ & ToLCV-[NP:Pan:00] & AY234383.1 & $94 \%$ \\
\hline $\begin{array}{l}\text { Tomato leaf curl virus strain TRN1, } \\
\text { complete genome }\end{array}$ & ToLCGV- TRN1 & KF612318.1 & $93 \%$ \\
\hline $\begin{array}{l}\text { Tomato leaf curl Gujrat virus complete viral } \\
\text { segment DNA-A, clone tlcgv-Xant }\end{array}$ & ToLCGV-[PK:Sum] & FR819708.1 & $93 \%$ \\
\hline $\begin{array}{l}\text { Tomato Leaf Curl Gujarat virus, complete } \\
\text { genome, clone SAZ-95_H-16-V-1-2 }\end{array}$ & ToLCGV & LN794215.1 & $93 \%$ \\
\hline $\begin{array}{l}\text { Tomato Leaf Curl Gujarat virus, complete } \\
\text { genome, clone SAZ-94_H-16-V-1-1 }\end{array}$ & ToLCGV & LN794214.1 & $93 \%$ \\
\hline $\begin{array}{l}\text { Tomato leaf curl Gujarat virus isolate } \\
\text { Ramgarh, complete genome }\end{array}$ & ToLCGV & GQ994098.1 & $93 \%$ \\
\hline $\begin{array}{l}\text { Tomato leaf curl Gujarat virus - [Dhanbad] } \\
\text { segment DNA-A, complete sequence }\end{array}$ & ToLCV-[IN:Dha:08] & EU573714.1 & $93 \%$ \\
\hline $\begin{array}{l}\text { Tomato leaf curl Gujarat virus-[Kelloo] } \\
\text { segment DNA-A, complete sequence }\end{array}$ & ToLCV-[IN:Mir:99] & AF449999.1 & $93 \%$ \\
\hline $\begin{array}{l}\text { Tomato leaf curl Gujarat virus isolate TC51 } \\
\text { segment DNA-A, complete sequence }\end{array}$ & ToLCGV-TC51 & KP164863.1 & $93 \%$ \\
\hline $\begin{array}{l}\text { Tomato leaf curl Gujarat virus - [Varanasi] } \\
\text { segment A, complete sequence }\end{array}$ & ToLCV-[IN:Var:01] & AY190290.1 & $93 \%$ \\
\hline $\begin{array}{l}\text { Tomato leaf curl New Delhi virus isolate } \\
\text { ToLCND-CTS segment DNA A, complete } \\
\text { sequence }\end{array}$ & ToLCV-[IN:ND:06] & DQ629101.2 & $93 \%$ \\
\hline $\begin{array}{l}\text { Tomato leaf curl Gujarat virus isolate } \\
\text { TC153 segment DNA-A, complete } \\
\text { sequence }\end{array}$ & ToLCGV-TC153 & KP164862.1 & $93 \%$ \\
\hline $\begin{array}{l}\text { Tomato leaf curl Gujarat virus-[Vadodara] } \\
\text { segment DNA-A, complete sequence }\end{array}$ & ToLCV-[IN:Vad:99] & AF413671.1 & $93 \%$ \\
\hline $\begin{array}{l}\text { Tomato leaf curl Gujarat virus isolate Frb- } \\
\text { Knp segment DNA-A, complete sequence }\end{array}$ & $\begin{array}{l}\text { ToLCV- } \\
{[\mathrm{IN}: \text { Frb- }}\end{array}$ & KF440686.1 & $93 \%$ \\
\hline $\begin{array}{l}\text { Tomato leaf curl Gujarat virus-[Pune:2008] clone } \\
\text { JGB2 segment DNA-A, complete sequence }\end{array}$ & ToLCV-[IN:Pun:08] & HM625838.1 & $92 \%$ \\
\hline $\begin{array}{l}\text { Tomato leaf curl Gujarat virus-[India:Valsad:2012] } \\
\text { isolate Valsad segment DNA-A complete sequence }\end{array}$ & $\begin{array}{l}\text { ToLCGV- } \\
\text { [India:Valsa d:2012] }\end{array}$ & KF515618.1 & $93 \%$ \\
\hline $\begin{array}{l}\text { Tomato leaf curl Gujarat virus isolate Tom, } \\
\text { complete sequence }\end{array}$ & ToLCGV & KR092195.1 & $92 \%$ \\
\hline
\end{tabular}


Table.2 Begomoviruses with their accession numbers from GenBank database used for sequence analysis and phylogenetic comparison

\begin{tabular}{|c|c|c|}
\hline Viruses & Virus-Acronym & $\begin{array}{c}\text { Accession } \\
\text { numbers }\end{array}$ \\
\hline $\begin{array}{l}\text { African cassava mosaic virus - [Nigeria:Ricinus } \\
\text { :2003] }\end{array}$ & ACMV-[NG:Rc:03] & EU685324.1 \\
\hline African cassava mosaic virus isolate & ACMV & NC_001467.1 \\
\hline $\begin{array}{l}\text { African cassava mosaic virus - [Central African } \\
\text { Republic:Bambari:CF35:2007] }\end{array}$ & ACMV-[CF:Bam:CF35:07] & HE814062.1 \\
\hline Chilli leaf curl India virus - [India::2008] & ChiLCINV-[IN::08] & FM877858.1 \\
\hline Chilli leaf curl virus - [India:Bhavanisagar:2010] & ChiLCV-[IN:Bha:10] & HM992939.1 \\
\hline Chilli leaf curl virus complete genome & ChiLCV & HE806437.1 \\
\hline $\begin{array}{l}\text { Chilli leaf curl virus - India } \\
\text { [India:Amritsar:Papaya:2009] }\end{array}$ & $\begin{array}{l}\text { ChiLCV-IN[IN: } \\
\text { Amr:Pap:09] }\end{array}$ & GU136803.1 \\
\hline Chilli leaf curl virus - [India:New Delhi:2010] & ChiLCV-[IN:ND:10] & JN663866.1 \\
\hline Chilli leaf curl virus isolate RK02 & ChiLCV-[RK02] & KJ700656.1 \\
\hline Chilli leaf curl virus isolate STS-02 & ChiLCV-[STS-02] & KR779820.1 \\
\hline Chilli leaf curl virus isolate Tom11 & ChiLCV & LN680633.1 \\
\hline Chilli leaf curl virus - India [India:Noida:2007] & ChiLCV-IN[IN:Noi:07] & HM007114.1 \\
\hline Cotton_leaf_curl_virus_isolate_Mohanp & CLCV-Moh & KC412251.1 \\
\hline Mungbean yellow mosaic India virus & MYMIV & NC_004608.1 \\
\hline $\begin{array}{l}\text { Mungbean yellow mosaic virus - [India:Panpozhi } \\
\text { PA1:2012] }\end{array}$ & MYMV-[IN:PanPA1:12] & KC911717.1 \\
\hline $\begin{array}{l}\text { Mungbean yellow mosaic virus - [Vietnam:Pnomh } \\
\text { Penh:2001] }\end{array}$ & MYMV-[VN:PP:01] & AY271892.1 \\
\hline $\begin{array}{l}\text { Mungbean yellow mosaic virus - [Viet Nam } \\
1: 2011]\end{array}$ & MYMV-[VN1:11] & JX244172.1 \\
\hline $\begin{array}{l}\text { Mungbean yellow mosaic virus - [India: Haryana } \\
\text { :2001] }\end{array}$ & MYMV-[IN:Har:01] & AY271896.1 \\
\hline $\begin{array}{l}\text { Mungbean yellow mosaic virus - [Thailand: } \\
\text { Mungbean 1] }\end{array}$ & MYMV-[TH:Mg1] & $\mathrm{AB} 017341.1$ \\
\hline $\begin{array}{l}\text { Bhendi yellow vein mosaic virus - [India: } \\
\text { Aurangabad:2009] }\end{array}$ & BYVV-[IN:Aur:09] & GU181356.1 \\
\hline $\begin{array}{l}\text { Papaya leaf curl virus - Rhynchosia [Pakistan } \\
\text { :Miangwali 68:Rhynchosia capitata:2008] }\end{array}$ & $\begin{array}{l}\text { PaLCuV- } \\
\text { Rh[PK:Mia68:Rc:0 }\end{array}$ & FM955602.1 \\
\hline Papaya leaf curl virus complete genome & $\mathrm{PaLCuV}$ & NC_004147.1 \\
\hline $\begin{array}{l}\text { Papaya leaf curl virus - Pakistan [Pakistan: Cotton } \\
: 2002]\end{array}$ & PaLCuV-PK[PK:Cot:02] & AJ436992.1 \\
\hline $\begin{array}{l}\text { Papaya leaf curl virus - Pakistan [India: } \\
\text { Pratapgarh:Crotalaria:2008] }\end{array}$ & $\begin{array}{l}\text { PaLCuV- } \\
\text { IN[IN:Pra:Cro:0 }\end{array}$ & GQ200446.1 \\
\hline $\begin{array}{l}\text { Papaya leaf curl virus - Amaranthus [India: } \\
\text { Lucknow:Amaranthus:2011] }\end{array}$ & $\begin{array}{l}\text { PaLCuV- } \\
\text { Ama[PK:Luc:Am:1 }\end{array}$ & JN135233.1 \\
\hline $\begin{array}{l}\text { Papaya leaf curl Guangdong virus - [Taiwan: Passi } \\
\text { flora:2011] }\end{array}$ & PaLCuGdV- [TW:Pas:11] & KC161184.1 \\
\hline $\begin{array}{l}\text { Papaya leaf curl virus - Tobacco [India: Lucknow } \\
\text { :Nicotiana glutinosa:2010] }\end{array}$ & $\begin{array}{l}\text { PaLCuV- } \\
\text { Tob[IN:Luc:Nic:10] }\end{array}$ & HM143914.1 \\
\hline
\end{tabular}


Table.2 Continued

\begin{tabular}{|c|c|c|}
\hline Viruses & Virus-Acronym & $\begin{array}{c}\text { Accession } \\
\text { numbers }\end{array}$ \\
\hline $\begin{array}{l}\text { South African cassava mosaic virus - [Zimbabwe } \\
\text { :Muzarabani:2003] }\end{array}$ & SACMV[ZW:Muz:03] & AJ575560.1 \\
\hline South_African_cassava_mosaic_virus_D & SACMV-D & NC_003803.1 \\
\hline $\begin{array}{l}\text { Sri Lankan cassava mosaic virus - India } \\
\text { [India:Adivaram:2003] }\end{array}$ & SLCMV-IN[IN:Adi:03] & AJ579307.1 \\
\hline $\begin{array}{l}\text { Tomato leaf curl Gujarat virus [Nepal] } \\
\text { [India:Nvs:LC:Tom:2016] }\end{array}$ & $\begin{array}{l}\text { ToLCGV [Nepal] } \\
\text { [India:Nvs:Tom:2016] }\end{array}$ & KU921251 \\
\hline $\begin{array}{l}\text { Tomato leaf curl Bangalore virus - B [India } \\
\text { :Bangalore 5] }\end{array}$ & ToLCBaV-B[IN:Ban5] & AF295401.1 \\
\hline Tomato leaf curl virus - [India:Dhanbad:2008] & ToLCV-[IN:Dha:08] & EU573714.1 \\
\hline Tomato leaf curl virus - [Nepal:Panchkhal:2000] & ToLCV-[NP:Pan:00] & AY234383.1 \\
\hline Tomato leaf curl virus - [India:Varanasi:2001] & ToLCV-[IN:Var:01] & AY190290.1 \\
\hline Tomato Leaf Curl Gujarat virus & ToLCGV & LN794215.1 \\
\hline Tomato Leaf Curl Gujarat virus & ToLCGV & LN794214.1 \\
\hline Tomato leaf curl Gujarat virus & ToLCGV & GQ994098.1 \\
\hline Tomato leaf curl virus - [India:Mirzapur:1999] & ToLCV-[IN:Mir:99] & AF449999.1 \\
\hline Tomato leaf curl virus - [India:Vadodara:1999] & ToLCV-[IN:Vad:99] & AF413671.1 \\
\hline $\begin{array}{l}\text { Tomato leaf curl gujarat virus - } \\
\text { [Pakistan:Summandri] }\end{array}$ & ToLCGV-[PK:Sum] & FR819708.1 \\
\hline Tomato leaf curl virus - [Iran:Iranshahr] & ToLCV-[IR:Ira] & AY297924.1 \\
\hline Tomato_leaf_curl_Karnataka_virus_com & ToLCKV & NC_003897.1 \\
\hline $\begin{array}{l}\text { Tomato leaf curl New Delhi virus - [Pakistan } \\
\text { :Multan:Momordica:2007] }\end{array}$ & $\begin{array}{l}\text { ToLCNDV- } \\
\text { [PK:Mul:Mom:07] }\end{array}$ & AM747291.1 \\
\hline $\begin{array}{l}\text { Tomato leaf curl New Delhi virus - [Thailand } \\
\text { :Bottle gourd:2006] }\end{array}$ & ToLCNDV-[TH:BG:06] & AB368447.1 \\
\hline Cherry tomato leaf curl virus - [India:CTM:2005] & CToLCV-[IN:CTM:06] & DQ629102.1 \\
\hline Tomato_leaf_curl_New_Delhi_virus_isol & ToLCNDV & KT426903.1 \\
\hline $\begin{array}{l}\text { Tomato leaf curl virus - } \\
\text { [India:Lucknow:Parthenium hysterophorus:2012] }\end{array}$ & ToLCV-[IN:Luc:Phy:12] & JX524172.1 \\
\hline Tomato leaf curl virus - [India:Erode:2012] & ToLCV-[IN:Ero:12] & JX547015.1 \\
\hline $\begin{array}{l}\text { Tomato leaf curl virus - } \\
\text { [India:Madurai:MDU1:2012] }\end{array}$ & $\begin{array}{l}\text { ToLCV- } \\
\text { [IN:Mad:MDU1:12] }\end{array}$ & KF612319.1 \\
\hline $\begin{array}{l}\text { Tomato leaf curl virus - } \\
\text { [India:Tirunelveli:TRN1:2012] }\end{array}$ & ToLCGV-TRN1 & KF612318.1 \\
\hline $\begin{array}{l}\text { Tomato yellow leaf curl virus - } \\
\text { [China:Shanghai:Tomato1:2008] }\end{array}$ & TYLCV-[CN:SH:Tom1:08] & GU434141.1 \\
\hline Tomato yellow leaf curl virus - [Kore] & TYLCV & KF225312.1 \\
\hline Tomato yellow leaf curl virus & TYLCV & KT355023.1 \\
\hline Tomato yellow leaf curl virus & TYLCV & KM435321.1 \\
\hline Tomato yellow leaf curl virus & TYLCV & HF548826.1 \\
\hline
\end{tabular}


Figure.1 Phylogenetic tree of sequences of ToLCGV [Nepal] [India:Nvs:LC:Tom:2016][KU921251] and previous reported Begomoviruses [Table 2]

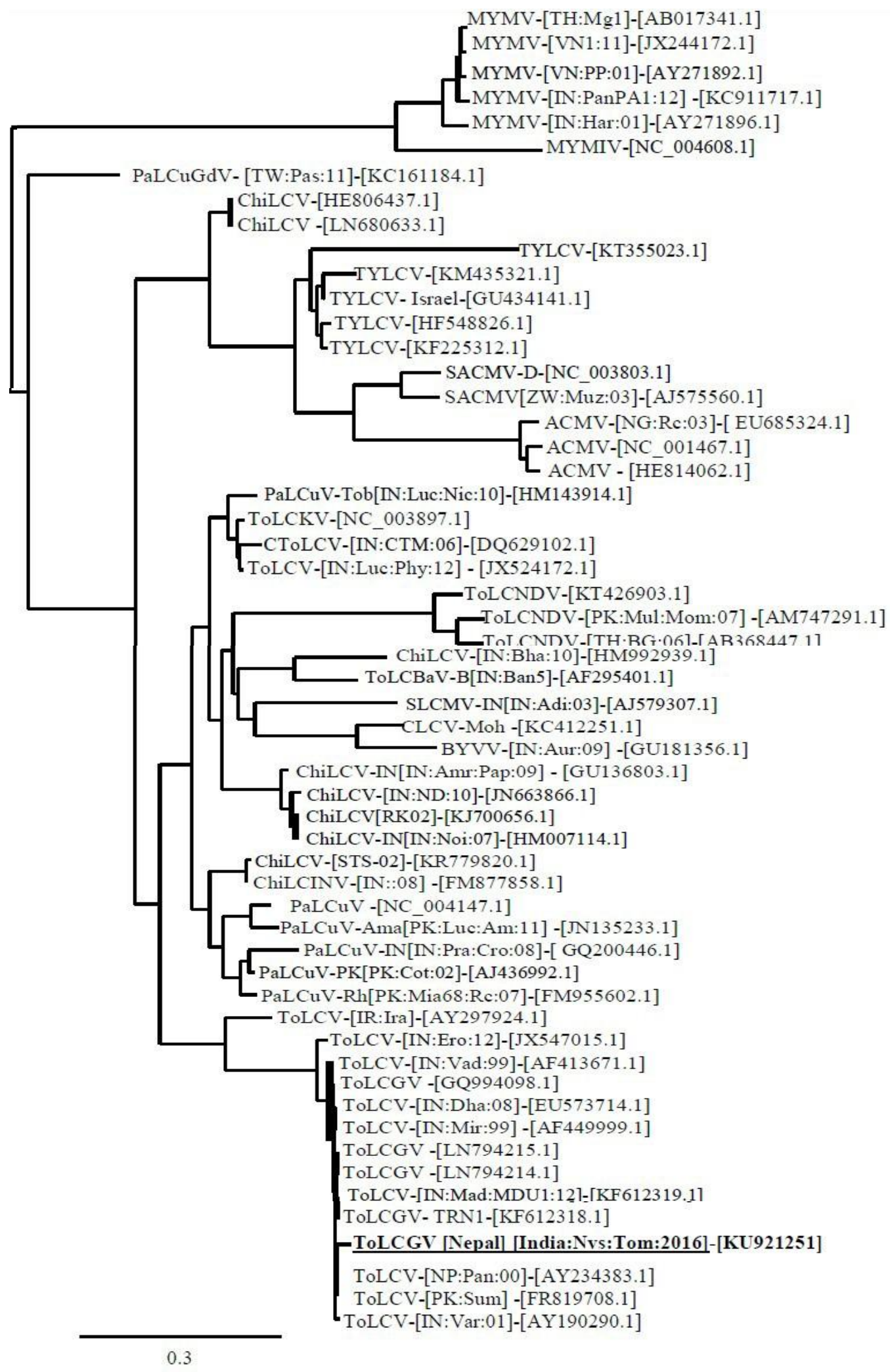


The tree was constructed by the full optimal alignment in the CLUSTALW2.0 and the neighbor joining method with 1000 bootstrap replications available in the MEGA4.0.

The genome organization of the Tomato leaf curl Gujarat virus [Nepal] [India: Nvs: Tom: 2016] was in agreement with the typical genome organization of Begomoviruses (Van et al., 2000; Navot et al., 1991). Amplification of the DNA-A fragment with the specific primers suggested that the virus in question is a Begomovirus. Further matching of ORF with other Begomoviruses confirmed the virus to be a Begomovirus. Different isolates of Tomato Yellow Leaf Curl Virus (TYLCV) align distinctly in separate clad in the phylogenetic tree prepared. This showed that the virus under investigation was found to be ToLCV and not TYLCV. Two distinct categories of virus producing different types of symptoms viz., Leaf Curl (LC) and Yellow Mottle (YM) are included in the ToLCD (Muniyappa et al., 2003; Rojas, 2004).

It is very difficult to recognize the symptoms of the viral disease by the virus name as found in other viruses. Yellow mottle and leaf curl are the two categories of symptoms produced by Tomato leaf curl disease. In the present study all the results were found supporting that virus studied was a leaf curl type virus which causes upward/ downward leaf curling along with the vein clearing of leaves and fruits, if produced were small, dry and unmarketable.

\section{References}

Anonymous. 2015. http://www.ictvonline. org/virusTaxonomy.asp page visited on 30.05.2015

Chakraborty, S., Pandey, P.K., Banerjee, M.K., Kalloo, G., Fauquet, C.M. 2003. Tomato leaf curl Gujarat virus, a new begomovirus species causing a severe leaf curl disease of tomato in Varanasi, India. Phytopathol., 93: 1485-1495.

Doyle, J.J. and Doyle, J.L. 1987. A rapid DNA isolation procedure for small quantities of fresh leaf tissue. Phytochem. Bull., 19: 11-15.

Fauquet, C.M., Briddon, R. W., Brown, J.K., Moriones, E., Stanley, J., Zerbini, M. and Zhou, X. 2008. Geminivirus strain demarcation and nomenclature. Arch Virol., 153: 783-821.

Mahatma, L., Mahatma, M.K., Pandya, J.R., Solanki, R.K. and Solanki, V.A. 2016. Epidemiology of Begomoviruses: A Global Perspective. In Plant Viruses: Evolution and Management (pp.171188). Springer Singapore.

Muniyappa, V., Maruthi, M.N., Babitha, C.R., Colvin, J., Briddon, R.W. and Rangaswamy, K.T. 2003. Characterization of Pumpkin Yellow Vein Mosaic Virus from India. Ann. Appl. Biol., 142: 323-331

Muniyappa, V., Swanson, M.M., Duncan, G. H. and Harrison, B.D. 1991. Particle purification, properties and epitope variability of Indian tomato leaf curl Geminivirus. Ann. Appl. Biol., 118: 595-604

Navot, N., Pichersky, E., Zeidan, M., Zamir, D., Czosnek, H. 1991. Tomato yellow leaf curl virus: A whitefly-transmitted Gemini virus with a single genomic component. Virol., 185: 151-161.

Pruthi, H.S. and Samuel, C.K. 1939. Entomological investigation on the leaf curl disease of tobacco in Northern India- III. The transmission of leaf curl by whitefly, Bemisia gossypipedra, to tobacco, sunhemp and a new alternate host of the leaf curl virus. Indian $J$. Agri. Sci., 9: 223-275.

Rojas, A. 2004. A complex of Begomoviruses affecting tomato crops in Nicaragua. Thesis, Ph.D., Swedish University of Agricultural Sciences, Department of 
Plant biology and forest genetics, Uppsala. 43pp

Sachan, V.K. 2004. Agrobios Newslett., 2: 3536.

Srivastava, K.M., Hallan, V., Raizada, R.K., Chandra, G., Singh, B.P. and Sane, V.P. 1995. Molecular cloning of Indian tomato leaf curl genome following a simple method of concentrating the supercoiled replicative form of viral DNA. J. Virol. Methods., 51: 297-304
Tamura, K., Dudley, J., Nei, M. and Kumar, S. 2007. MEGA4: Molecular Evolutionary Genetics Analysis (MEGA) software version 4.0.

Van Rogenmortel, M.H.V., Fauquet, C.M., Bishop, D.H.L., Carstens, E., Estes, M.K., Lemon, S.M., Maniloff, J., Mayo, M.A., McGeoch, D.J., Pringle, C.R. and Wickner, R.B. 2000. Virus Taxonomy. VIIth Report of the International Committee on Taxonomy of Viruses, San Diego: Academic Pr.

\section{How to cite this article:}

Vanthana, M., L. Mahatma., T.V. Ghevariya and Saranya, R. 2017. Molecular Characterization of Tomato Leaf Curl Virus (ToLCV) In South Gujarat. Int.J.Curr.Microbiol.App.Sci. 6(3): 473481. doi: https://doi.org/10.20546/ijcmas.2017.603.055 